\title{
Improving administrative control over the legality of local government decisions
}

\author{
Svitlana Diachenko ${ }^{1, *}$ and Volodymyr Buha $^{2}$ \\ ${ }^{1}$ National Academy for Public Administration under the President of Ukraine, Ukraine \\ ${ }^{2}$ Donetsk State University of Internal Affairs, Ukraine
}

\begin{abstract}
The article is devoted to the issues of territorial development, the role of local self-government bodies in ensuring the processes of planning and management of territories, the system of administrative control over territorial development. Territorial development has great state importance. The standard of living and income of the population are directly related to the resource, economic, technological potential of the territories and the system of territory management. Thus, the issue of managing territorial development by improving the efficiency of local governments is relevant. The article considers the main functions of local governments at the territorial level. The functional direction of territorial administration at the level of local self-government is regulated by the legal framework. The system of normative-legal regulation of territorial development processes, functioning of local self-government bodies are described in the article. The role of local governments, public authorities and the private sector in the implementation of territorial management policy and the implementation of a system of control over the adoption and effective implementation of management decisions on territorial development. The practical significance of the results obtained in the article is to determine the role of local governments in the system of territorial development. This is necessary to build a clear hierarchical system of territorial management at the level of local entities, regions, the state as a whole. The system will allow to distribute management functions, effectively monitor and control their implementation by introducing administrative control at different levels of implementation of management decisions.
\end{abstract}

\section{Articulation of Issue}

Territorial development is an urgent issue. According to the practice of European countries, the most effective is the system of territorial management, built on the expanded functions of local self-government. The European vector of development of local selfgovernment bodies is set out in the normative document "European Charter of Local SelfGovernment". In particular, the document states that: «The Charter obliges states to enshrine in their domestic legislation and apply in practice a set of legal norms guaranteeing the political, administrative and financial independence of municipalities» [1].

\footnotetext{
* Corresponding author: lana.dyachenko@gmail.com
} 
Thus, the Charter defines the role and place of local self-government bodies in the processes of territorial development. However, the expansion of powers and the granting of additional rights raises the issue of finding effective systems to control the adoption and implementation of management decisions at the local level. Accordingly, the urgency of administrative control issues is growing. The processes of ensuring administrative control over the status of local self-government are becoming more complicated. The election of local governments does not allow public sector institutions to influence the decisions of local authorities. Thus, the regulatory policy of the local government system and the adoption and implementation of management decisions should be laid down in the regulatory system. Accordingly, the system "public sector-local governments-territorial development" is created.

\section{Analysis of the Latest Researches and Publications}

The issue of territorial development is of great practical importance. Many scientists have worked on its solution. Also, many works are devoted to topical issues of local government development, their role in territorial development, delimitation of their functions and powers with public authorities in order to obtain the most positive effect of such management work of different branches of government. Thus, the following scientists dealt with the development of territories and the development of local self-government: Jesse C. Ribot, Eleonora Cardillo and Maria Cristina Longo, Xiang Gao \&Jianxing Yu, Haitao Wuabc, Yunwei Lid, Yu Haoabefg, Siyu Renc Pengfei Zhangh, Dag Ingvar Jacobsen \&Åge Johnsen [2-7]. However, changes in society pose new challenges for scientists to improve the results of research. So, let's define some elements of this question.

\section{Purposes and Objectives}

The purpose of the article is to determine the role of local governments in the system of spatial planning in order to build a system of effective administrative control of management decisions at the local level.

According to the purpose of the article, the following tasks are set:

- analyse the specifics of territorial development,

- to analyse the essence of the concept of local self-government,

- to determine the functions of local self-government in the system of territorial planning,

- outline the regulatory framework for territorial development,

to define regulatory mechanisms of administrative decisions of city self-government bodies by definition of elements of administrative control.

\section{Statement of Basic Materials}

Territorial development is an important element of state development. Territorial management involves a set of systemic factors of its development, namely: urban planning aspects, socio-economic aspects, environmental aspects, cultural and household aspects and development of civil society. At each stage of some aspect realization of territories management the important component is maintenance of the control of acceptance of administrative decisions. Issues of control over the implementation of management decisions at the territorial level have a legislative component, the system of organization of executive branches, technical aspects, socio-economic component and issues of efficiency of local governments. Therefore, considering the issue of administrative control of 
decision-making by local governments, it is advisable to identify certain elements of this system.

Defining the specifics of local governments and their role in ensuring territorial development is defined in the European Charter of Local Self-Government «Local authorities, acting within the limits of the law, are to be able to regulate and manage public affairs under their own responsibility in the interests of the local population. Consequently, the Charter considers that public responsibilities should be exercised preferably by the authorities closest to the citizens, the higher level being considered only when the coordination or discharge of duties is impossible or less efficient at the level immediately below» [1].

It is possible to present in the form of the following scheme of elements groups of administrative control within the limits of maintenance of territories development by realization local governments functions - Fig. 1

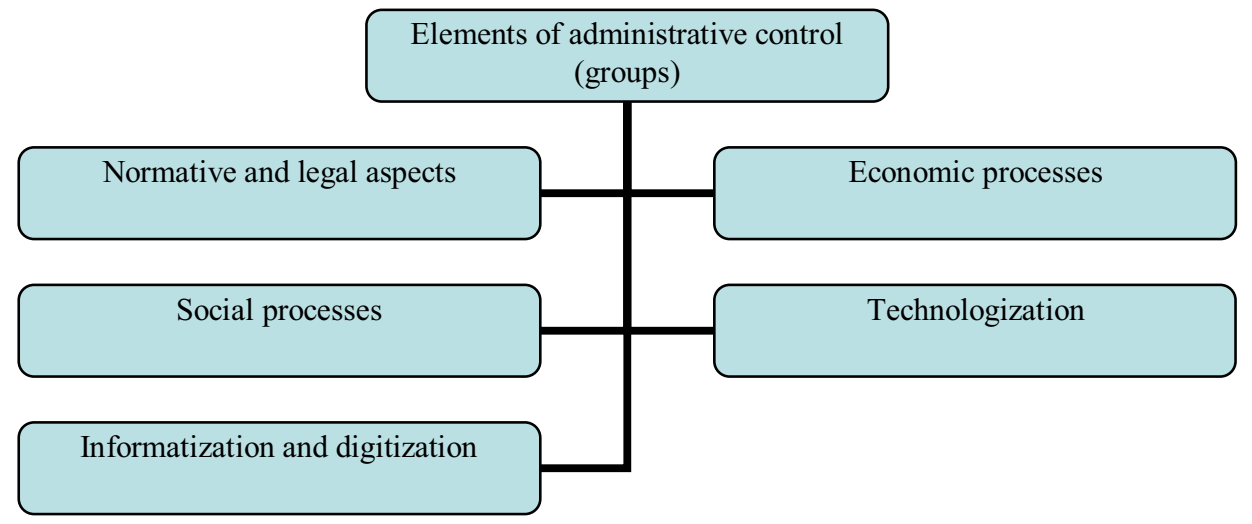

Fig. 1. Elements of administrative control (groups) [2-3].

Table 1 presents a list of controls developed by the author. The described elements characterize the sequence and systematization of administrative control taking into account specific aspects of territorial development and territorial planning and management.

Table 1. The described elements characterize the sequence and systematization of administrative control [4-6].

\begin{tabular}{|l|l|l|}
\hline Name & \multicolumn{1}{|c|}{ Structural elements } & \multicolumn{1}{|c|}{ Characteristic } \\
\hline $\begin{array}{l}\text { Normative and } \\
\text { legal aspects } \\
\text { internal documents, } \\
\text { regulations, decisions of } \\
\text { councils of different levels, } \\
\text { orders, decrees, other } \\
\text { documents of executive bodies } \\
\text { at the local level and local self- } \\
\text { government bodies, sets of } \\
\text { norms and rules, etc. }\end{array}$ & $\begin{array}{l}\text { The normative-legal } \\
\text { documents" characterizes the system } \\
\text { of norms and rules of territorie's } \\
\text { development. These norms and rules } \\
\text { are established by the community } \\
\text { itself in accordance with the current } \\
\text { legislation of the state within the } \\
\text { rights and powers of local } \\
\text { governments. }\end{array}$ \\
\hline $\begin{array}{l}\text { Economic } \\
\text { processes }\end{array}$ & $\begin{array}{l}\text { providing the population with } \\
\text { jobs, } \\
\text { development of industry and } \\
\text { agriculture, } \\
\text { development of other economy } \\
\text { branches, first of all, }\end{array}$ & $\begin{array}{l}\text { Legislative regulation of opportunities } \\
\text { for economic, business and investment } \\
\text { climate development. Creating } \\
\text { conditions for economic development } \\
\text { through the development of effective } \\
\text { regulatory mechanisms at the public }\end{array}$ \\
\hline
\end{tabular}




\begin{tabular}{|c|c|c|}
\hline & $\begin{array}{l}\text { construction and sphere of } \\
\text { services (that provides increase } \\
\text { of living comfort of the } \\
\text { territories population), } \\
\text { level of the population income, } \\
\text { business activity and business } \\
\text { opportunities, } \\
\text { favorable investment climate, } \\
\text { etc. }\end{array}$ & $\begin{array}{l}\text { level and through the transfer of a } \\
\text { number of powers to local } \\
\text { governments }\end{array}$ \\
\hline Social processes & $\begin{array}{l}\text { ensuring a proper standard of } \\
\text { living for the population, } \\
\text { providing comfortable living } \\
\text { conditions for the population } \\
\text { on the territory, } \\
\text { ensuring the appropriate level } \\
\text { of social services, } \\
\text { development of civil society, } \\
\text { intensification of the civil } \\
\text { movement }\end{array}$ & $\begin{array}{l}\text { Legislative support of the social } \\
\text { services system and increase of } \\
\text { population living comfort taking into } \\
\text { account modern requirements to } \\
\text { territories urbanization, development } \\
\text { of public activism as an element of the } \\
\text { control system of decisions execution } \\
\text { of local governments }\end{array}$ \\
\hline \multirow[t]{2}{*}{ Technologization } & $\begin{array}{l}\text { introduction of innovation } \\
\text { technologies in various spheres } \\
\text { of economic activity, } \\
\text { introduction of innovative } \\
\text { technologies in various spheres } \\
\text { of social security, } \\
\text { introduction of innovation } \\
\text { technologies in various spheres } \\
\text { into the system of public } \\
\text { administration, } \\
\text { introduction of innovation } \\
\text { technologies in various spheres } \\
\text { into the system of local self- } \\
\text { government, in innovative } \\
\text { introduction of iferent } \\
\text { technologies in diffes } \\
\text { spheres in some spheres of life } \\
\text { and social development, }\end{array}$ & $\begin{array}{l}\text { Implementation of norms, rules and } \\
\text { standards for all technical and } \\
\text { technological processes, the } \\
\text { implementation of which is within the } \\
\text { competence of local governments. } \\
\text { First of all, this applies to the system } \\
\text { of housing and communal services. } \\
\text { After all, this is the largest technical } \\
\text { system, which is controlled by local } \\
\text { governments, is on the statement of } \\
\text { financial position and in the work of } \\
\text { the community. }\end{array}$ \\
\hline & $\begin{array}{l}\text { introduction of innovative } \\
\text { technologies } \\
\text { ensuring the aim of } \\
\text { standards }\end{array}$ & \\
\hline $\begin{array}{l}\text { Informatization } \\
\text { and digitization }\end{array}$ & $\begin{array}{l}\text { development of systems for } \\
\text { selection, evaluation, analysis } \\
\text { of information to support } \\
\text { management decisions at the } \\
\text { level of local governments, } \\
\text { monitoring of information } \\
\text { flows within the territory and } \\
\text { from the external environment, } \\
\text { creation an information system } \\
\text { which use not in the format of } \\
\text { statistical data, but in the } \\
\text { format of consulting services } \\
\text { information support at the level } \\
\text { of local self-government } \\
\text { bodies, } \\
\text { digitalization of life support }\end{array}$ & $\begin{array}{l}\text { Development of regulatory } \\
\text { documents, algorithms for working } \\
\text { with information flows. Putting into } \\
\text { practice the work of local governments } \\
\text { and livelihoods of digital technologies } \\
\text { in order to increase the level of life } \\
\text { comfort. }\end{array}$ \\
\hline
\end{tabular}




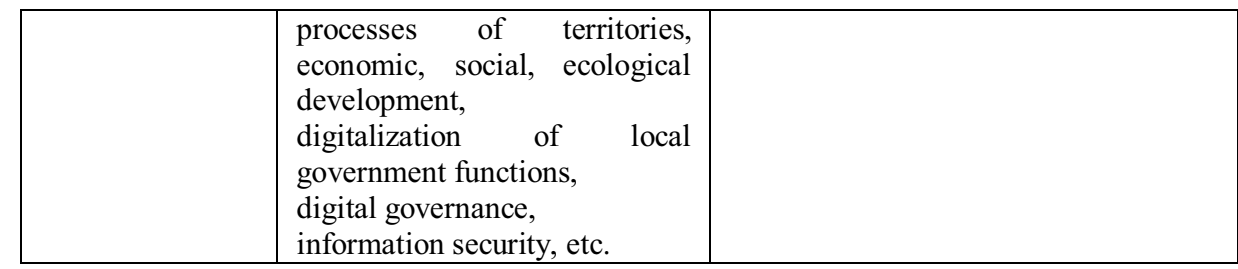

Analysis of the elements of the administrative control system allowed to determine its functional areas. According to the results of the characteristics of the elements, it is determined that each function can be implemented at different levels of territorial management. It is important to analyze the level of legislative support for territorial development functions by determining the role of administrative control in the territorial management system.

The results of the analysis are presented in table 2

Table 2. Description of the legislative regulation level of administrative control functions.

\begin{tabular}{|c|c|c|}
\hline Structural elements & $\begin{array}{c}\text { The place of local } \\
\text { governments }\end{array}$ & Control system \\
\hline $\begin{array}{l}\text { regulations, decisions of councils } \\
\text { of different levels, orders, decrees, } \\
\text { other documents of executive } \\
\text { bodies at the local level and local } \\
\text { self- government bodies }\end{array}$ & $\begin{array}{l}\text { Making and implementing } \\
\text { management decisions for } \\
\text { territorial planning and } \\
\text { development }\end{array}$ & $\begin{array}{l}\text { Control and audit } \\
\text { bodies, the public }\end{array}$ \\
\hline Sets of norms and rules, etc. & $\begin{array}{l}\text { Special bodies of the relevant } \\
\text { profile at the state level and } \\
\text { their structural subdivisions } \\
\text { on the territory }\end{array}$ & $\begin{array}{l}\text { Special bodies of the } \\
\text { different levels }\end{array}$ \\
\hline Providing the population with jobs & $\begin{array}{l}\text { Employment services at the } \\
\text { level of territories and the } \\
\text { state }\end{array}$ & $\begin{array}{l}\text { Community, public } \\
\text { authorities }\end{array}$ \\
\hline $\begin{array}{l}\text { Development of industry and } \\
\text { agriculture and other economy } \\
\text { branches }\end{array}$ & $\begin{array}{l}\text { Creating conditions for the } \\
\text { development of various } \\
\text { sectors of the economy }\end{array}$ & $\begin{array}{l}\text { Relevant Ministries and } \\
\text { agencies, local } \\
\text { governments, } \\
\text { communities, } \\
\text { specialized agencies (eg } \\
\text { environmental } \\
\text { inspections) }\end{array}$ \\
\hline Level of the population income & $\begin{array}{l}\text { Creating conditions for the } \\
\text { social development }\end{array}$ & $\begin{array}{l}\text { Public and private } \\
\text { sector, local } \\
\text { governments, } \\
\text { investment, consulting, } \\
\text { business institutions }\end{array}$ \\
\hline $\begin{array}{l}\text { Business activity and business } \\
\text { opportunities }\end{array}$ & $\begin{array}{lr}\text { Creating conditions for the } \\
\text { development } & \text { business } \\
\text { environment, } & \text { open } \\
\text { competitive market } & \end{array}$ & $\begin{array}{l}\text { Public and private } \\
\text { sector, local } \\
\text { governments, } \\
\text { investment, consulting, } \\
\text { business institutions }\end{array}$ \\
\hline Favorable investment climate & $\begin{array}{l}\text { Creating conditions for the } \\
\text { opportunities for safe and } \\
\text { profitable investment }\end{array}$ & $\begin{array}{l}\text { Public and private } \\
\text { sector, local } \\
\text { governments, } \\
\text { investment, consulting, } \\
\text { business institutions }\end{array}$ \\
\hline $\begin{array}{l}\text { Ensuring a proper standard of } \\
\text { living for the population, providing } \\
\text { comfortable living conditions }\end{array}$ & $\begin{array}{l}\text { Provision of life support } \\
\text { systems of territories }\end{array}$ & $\begin{array}{l}\text { Local governments, } \\
\begin{array}{l}\text { utilities, the public } \\
\text { sector }\end{array}\end{array}$ \\
\hline
\end{tabular}




\begin{tabular}{|c|c|c|}
\hline $\begin{array}{l}\text { Innovation technologies in various } \\
\text { spheres of economic activity, social } \\
\text { security, system of public } \\
\text { administration, system of local } \\
\text { self-government }\end{array}$ & $\begin{array}{l}\text { Scientific developments } \\
\text { implemented in practice in } \\
\text { order to increase the comfort } \\
\text { of life and development of } \\
\text { territories }\end{array}$ & $\begin{array}{lr}\begin{array}{l}\text { Design and } \\
\text { organizations, }\end{array} & \text { research } \\
\text { institutions, } & \\
\text { development } & \text { centers, } \\
\text { scientific community, } \\
\text { inventors r } \\
\text { innovators, consulting } \\
\text { institutions }\end{array}$ \\
\hline $\begin{array}{l}\text { Development of systems for work } \\
\text { with information to support } \\
\text { management decisions at the level } \\
\text { of local governments, monitoring } \\
\text { of information flows, digitalization } \\
\text { of life support processes of } \\
\text { territories, economic, social, } \\
\text { ecological development, local } \\
\text { government functions, governance, } \\
\text { information security etc. }\end{array}$ & $\begin{array}{l}\text { Creation of modern } \\
\text { information systems to } \\
\text { support } \\
\text { decisions. Development of } \\
\text { algorithms for working with } \\
\text { information streams. Digital } \\
\text { support for territorial } \\
\text { management through the } \\
\text { development of modern } \\
\text { software and automated } \\
\text { control systems. Digital } \\
\text { marketing of territories }\end{array}$ & $\begin{array}{l}\text { Local governments, } \\
\text { utilities, the public } \\
\text { sector, private sector: } \\
\text { IT companies, public } \\
\text { relations specialists, } \\
\text { marketers }\end{array}$ \\
\hline
\end{tabular}

Summarizing the above, the analysis allowed to determine the functions of the system of administrative control of management decisions of local governments and the level of its implementation in the system of territorial development.

\section{Conclusions}

Conclusion. As a result of the study, the following was determined. The activity of local self-government bodies is a basic element of life territories support. Territorial development is a systemic and multifactorial concept. Thus, the set of functions of local governments can be structured by certain functional blocks. The functional blocks of territorial development were identified in the article. This list includes the following items: Normative and legal aspects, Economic processes, Social processes, Technologization, Informatization and digitization. Each block was given a characteristic. The level and role of local selfgovernment in performing the functions of each of the blocks are determined. The role of the administrative control system is determined by analyzing the legislative support of each of the functions of territorial development. The result of the study was a structured system of local governments and systems functions of administrative control over them.

\section{References}

1. European Charter of Local Self-Government (Strasbourg, 1985) https://www.coe.int/en/web/conventions/full-list/-/conventions/treaty/122

2. Jesse C. Ribot, Cambridge University Press 69(1) (2011) DOI: https://doi.org/10.2307/1161076

3. E. Cardillo, M.C. Longo, Sustainability 12(9), 3675 https://doi.org/10.3390/su12093675

4. Xiang Gao, Jianxing Yu, Public governance mechanism in the prevention and control of the COVID-19: information, decision-making and execution, https://doi.org/10.1080/23812346.2020.1744922 
5. Omar Ali Valmira Osmanaj, The role of government regulations in the adoption of cloud computing: A case study of local government, https://doi.org/10.1016/j.clsr.2020.105396

6. Haitao Wuabc, Yunwei Lid, Yu Haoabefg, Siyu Renc Pengfei Zhangh, Environmental decentralization, local government competition, and regional green development: Evidence from China, https://doi.org/10.1016/j.scitotenv.2019.135085

7. Dag Ingvar Jacobsen, Åge Johnsen, Alignment of strategy and structure in local government (2020) https://doi.org/10.1080/09540962.2020.1715093 